\title{
Aphid Species Colonizing Perennial Asteraceae Host Species along Hungarian Motorways
}

\author{
ZS. BASKY \\ Plant Protection Institute, Centre for Agricultural Research, Hungarian Academy of Sciences, \\ Herman Ottó u. 15, H-1022 Budapest, Hungary
}

(Received: 12 January 2016; accepted: 25 January 2016)

\begin{abstract}
Uroleucon cichorii (Koch, 1855) Aphis intybii (Koch, 1855) and Aphis fabae cirsiiacanthoidis Scopoli, 1763 colonies occurred on Cichorium intybus L., Cirsium arvense (L.) Scop. was colonised by Aphis fabae cirsiiacanthoidis. Artemisia vulgaris L. accommodated Macrosiphoniella artemisiae (Boyer de Fonscolombe, 1841). The annual Crepis setosa Haller was the host plant of Uroleucon cirsii (Linnaeus, 1758) and Uroleucon cichorii. The perennial Picris hieracioides L. also accommodated Uroleucon cirsii. Centaurea arenaria M. Bieb. ex Willd. and Centaurea stoebe L. subsp. micranthos (Gugler) Hayek accommodated Uroleucon jaceae (Linnaeus, 1758). Carduus acanthoides L. was colonized by Uroleucon aeneum (Hille Ris Lambers, 1939). Artemisia absinthium L. was the host of Macrosiphoniella absinthii (Linnaeus, 1758). Achillea millefolium L. was colonized by Macrosiphoniella millefolii (De Geer, 1773).
\end{abstract}

Keywords: Uroleucon, Macrosiphoniella, Aphid species, Hungary.

Establishment of motorways starts with levelling of the ground for the road bed construction (Forman et al., 2002). Depending of the configuration of the terrain the removed soil layer can be not thicker than 15-20 cm. During this procedure the natural vegetation is destroyed. However, the remaining root layer of the perennial plant species serves propagation purposes. We observed it in case of Silene alba (Mill.) E.H.L. Krause 1893 (Basky, 2015). Silene alba occurred more often on the youngest highway section. In case of Asteraceae plant species out of 11 aphid colonized daisy species ten species are perennial. The only annual host species accommodated aphid was Crepis setosa.

\section{Materials and Methods}

Aphids were surveyed on host plants from middle of May till the beginning of July in 2011 and 2012 along the 2655.9 km long highway network of Hungary. Thirty-three evenly distributed sampling places were marked along the highways. The sampling places are published in Kiss et al. (2013). Aphids were collected from host plants with fine camel hair brush. The collected aphid individuals were placed into Eppendorf tubes containing $70 \%$ ethanol. Location, sampling date and host plant name were recorded on the labels 
placed into the tubes. Apterous individuals were slide mounted using the method of Szalay-Marzsó (1969). The scientific name of host plants is used according to Király (2009).

\section{Results}

The aphid species colonizing host plants belonging to family Asteraceae are summarized in this paper. The paper is not a botanical survey; therefore it does not deal with the frequency of the host plant along the Hungarian motorway network. Host plants were surveyed for the presence of aphid colonies. Host species accommodated aphids are listed. Aphids were identified to species level. Altogether 10 Asteraceae plant species were found aphid infested. Out of the 10 composite host species only Crepis setosa Haller is an annual plant. Nine species are perennial, they are the following: Cichorium intybus L., Cirsium arvense (L.) Scop., Artemisia vulgaris L., Picris hieracioides L., Centaurea arenaria M. Bieb. ex Willd., Centaurea stoebe subsp. micranthos (Gugler) Hayek, Carduus acanthoides L., Artemisia absinthium L. and Achillea millefolium L. Cichorium intybus was the most frequently colonized host plant by aphids. Aphid colonies were present on $C$. intybus in 12 cases. Uroleucon cichorii (Koch, 1855) was the most frequently collected species (at 7 sampling places).

Uroleucon cichorii (Koch, 1855) colonized the upper part of the stems of C. intybus. The species is monoecious, holocyclic. This species is able to colonize Crepis, Hieracium, Lactuca, Lapsana and Leontodon species. The area of distribution of U. cichorii is Europa, South West and Cental Asia, Mongolia, East Siberia (Blackman and Eastop, 2006).

Uroleucon cichorii is a large aphid (body length: 2.7-4.7 $\mathrm{mm}$ ) apterae are metallic brown, antennae, legs and siphunculy are black. Dorsal hairs on ABD TERG 4-5 mainly originating from dark scleroites. Cauda is pale yellow. The presence of crescent shaped antesiphuncular sclerites separates the species from other Uroleucon species (Fig. 1).

Aphis intybi Koch, 1855 was the second most frequently collected species on C. intibus (4 sampling places). A. intybi was found on young shoots, later at stem bases. Colonies were ant attended. It is monoecious holocyclic on Cichorium (Stoetzel and Russell, 1991). The species is present in Europe, Mediterranean region, West and Central Asia and it was reported at ports of entry to USA (Stoetzel and Russell, 1991).

Aphis intybi (body length: 1.2-2.3 mm) the body is, black wax-powdered. Cauda, legs, and cornicles are also black. A black or very dark brown species with a variable abdominal sclerotic pattern - confined to abdominal tergites 6-8 in smaller apterae but broken bands present in larger ones (Fig. 2).

Aphis fabae cirsiiacanthoides Scopoli, 1763 was found on C. intibus in one occasion. The species is heterooceous, it overwinters on Euonymus europaeus L., Viburnum opulus L. or on Philadelphus coronarius L. The principal summer host of the species is Cirsium arvense (Blackman and Eastop, 2006).

Aphis fabae cirsiiacanthoides is a medium sized aphid (body length is $1.2-2.9 \mathrm{~mm}$ ) A black species with a variable abdominal sclerotic pattern - confined to abdominal tergites 6-8. The siphunculi and cauda are black. The antennae have joints of III-IV and 


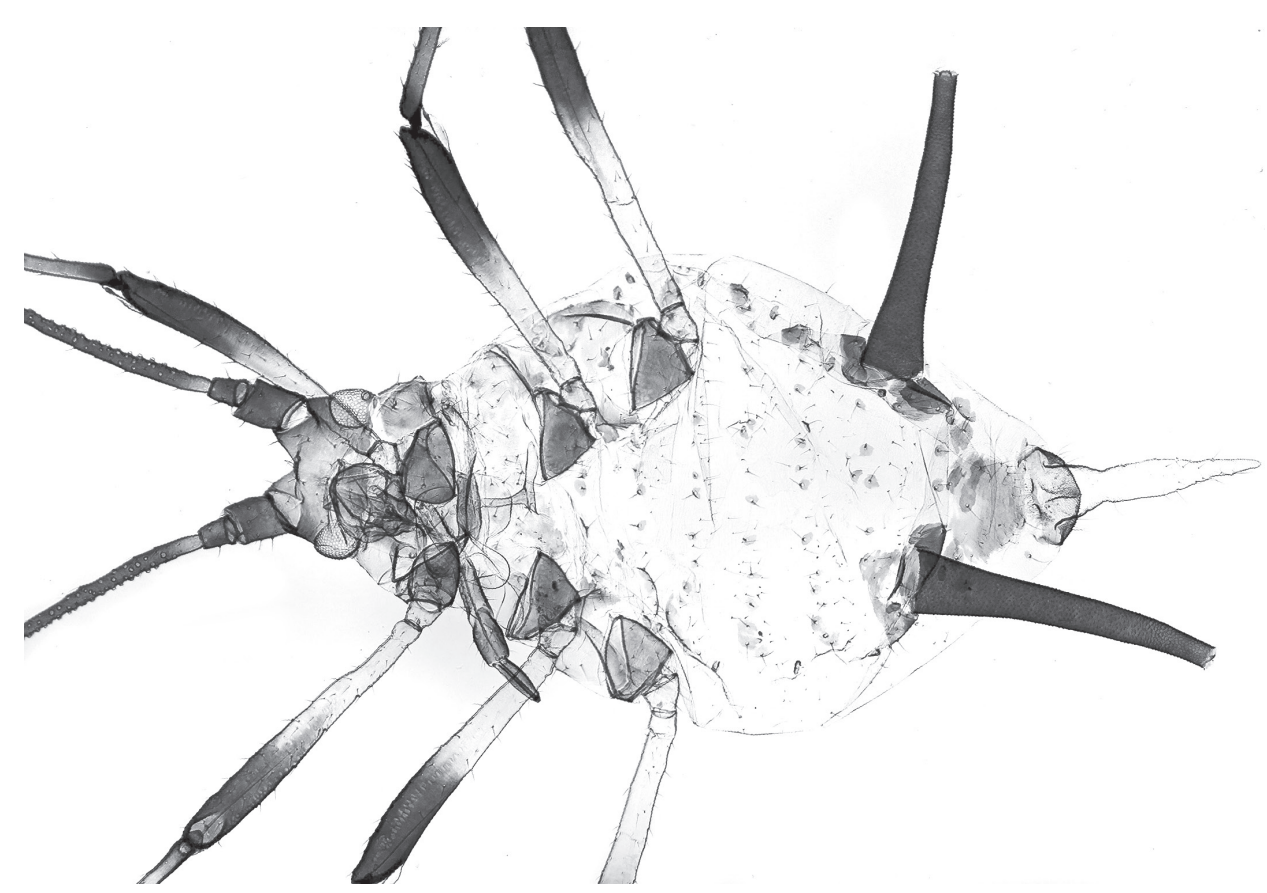

Fig. 1. Uroleucon cichorii

base of V usually quite pale. Small marginal tubercles are present. Apterae and nymphs often have discrete white wax spots (Fig. 3).

Cirsium arvense was colonized by aphids in 6 locations. Aphis fabae cirsiiacanthoides was collected from 5 locations. In one location only nymphs were present on the thistle. Therefore it was not possible to identify the species. However, based on the other collections it can be supposed that the collected nymps were the immature individuals of Aphis fabae cirsiiacanthoides.

Artemisia vulgaris L. was colonized by Macrosiphoniella artemisiae (Boyer de Fonscolombe, 1841) on 4 locations. Macrosiphoniella artemisiae forms colonies on the upper parts on A. vulgaris. The species is monoecious, holocyclic on Artemisia vulgaris. The species colonizes other Artemisia species and Leucanthemum vulgare and Tanacetum parthenium. The distribution area of M. artemisiae is the whole Europe, eastward to Siberia, Mongolia and China. The species was introduced to North America (Blackman and Eastop, 2006).

Macrosiphoniella artemisiae is a greyish green, wax dusted medium large aphid with black appendages (body length is 2.3-3.6 mm). Macrosiphoniella artemisiae has stiletto-shaped RIV-V. Distal half of the siphunculi has polygonal reticulation. The abdomen is entirely pale because the body hairs are originating from pale scleroites (Fig. 4).

Crepis setosa was colonized by aphids in 6 locations. Uroleucon cirsii was present on $C$. setosa on 4 locations. In two locations Uroleucon cichorii was collected from C. setosa. 


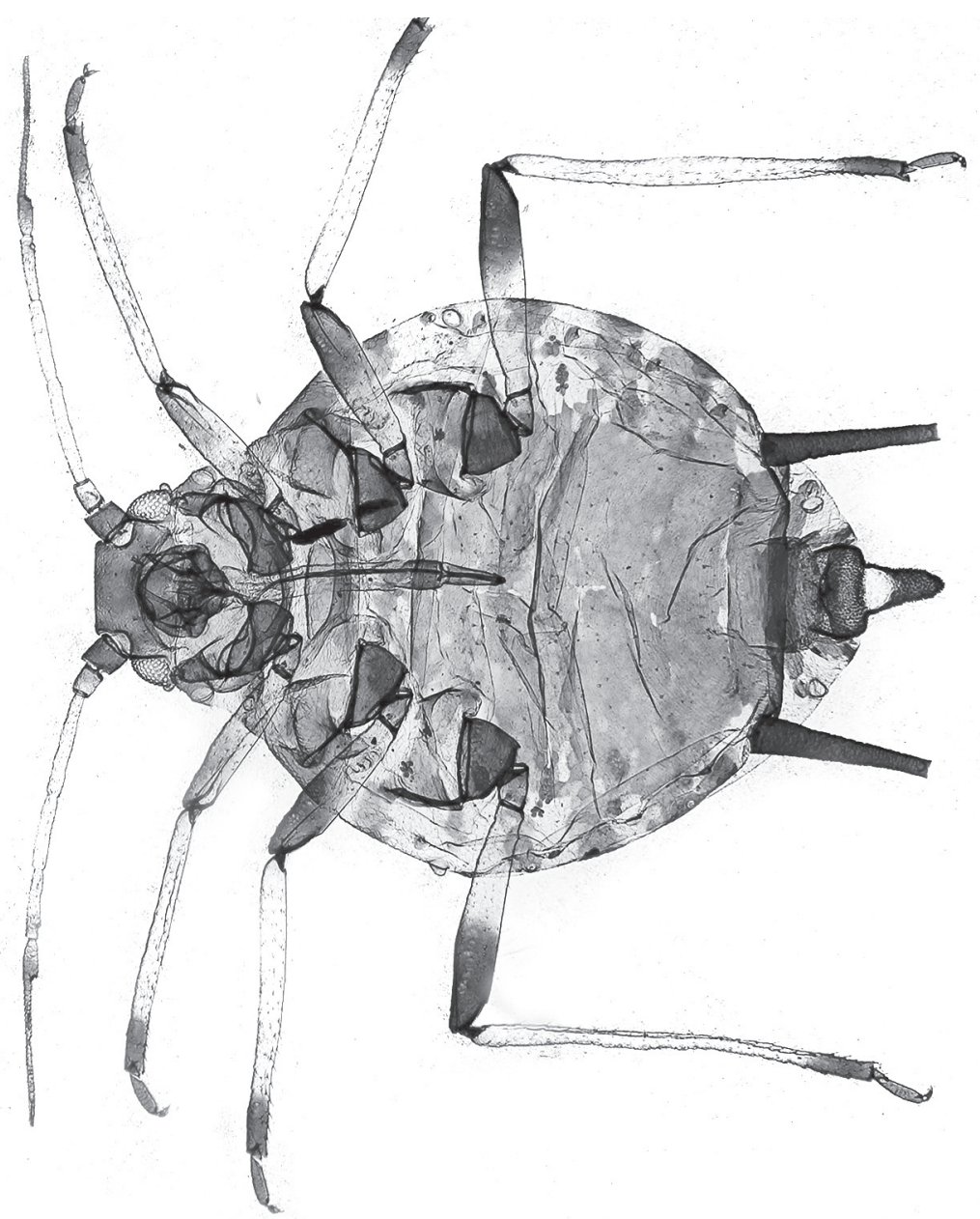

Fig. 2. Aphis intybii

Uroleucon cirsii is monoecious, holocyclic on Cirsium. The species is widespread in Europe and Russia to Western Siberia. It was introduced to North America (Blackman and Eastop, 2006).

Uroleucon cirsii is a large reddish brown aphid with pale distally darkened legs (body length: 3.2-5.2 mm). A crescent shaped sclerite is present in front of each long black siphunculus. There is polygonal reticulation on distal part of siphunculi. Abdominal hairs are placed on pigmented scleroites. Spinal scleroites are fused into larger sclerites, each normally with three hairs. The slightly dusky cauda has 20-33 hairs (Fig. 5).

Uroleucon cirsii occurred on Picris hieracioides in one location. This is a new host plant record for the species. 


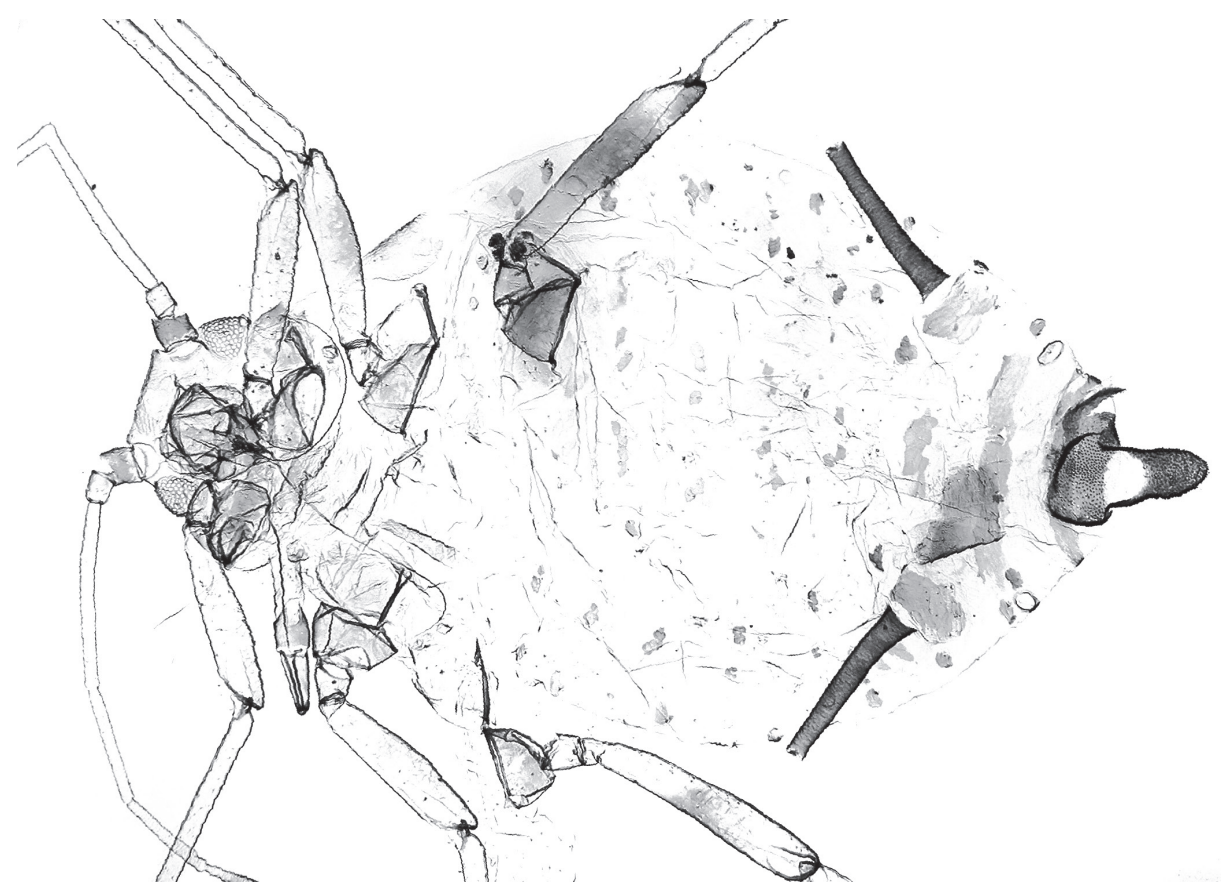

Fig. 3. Aphis fabae cirsiiacanthoidis

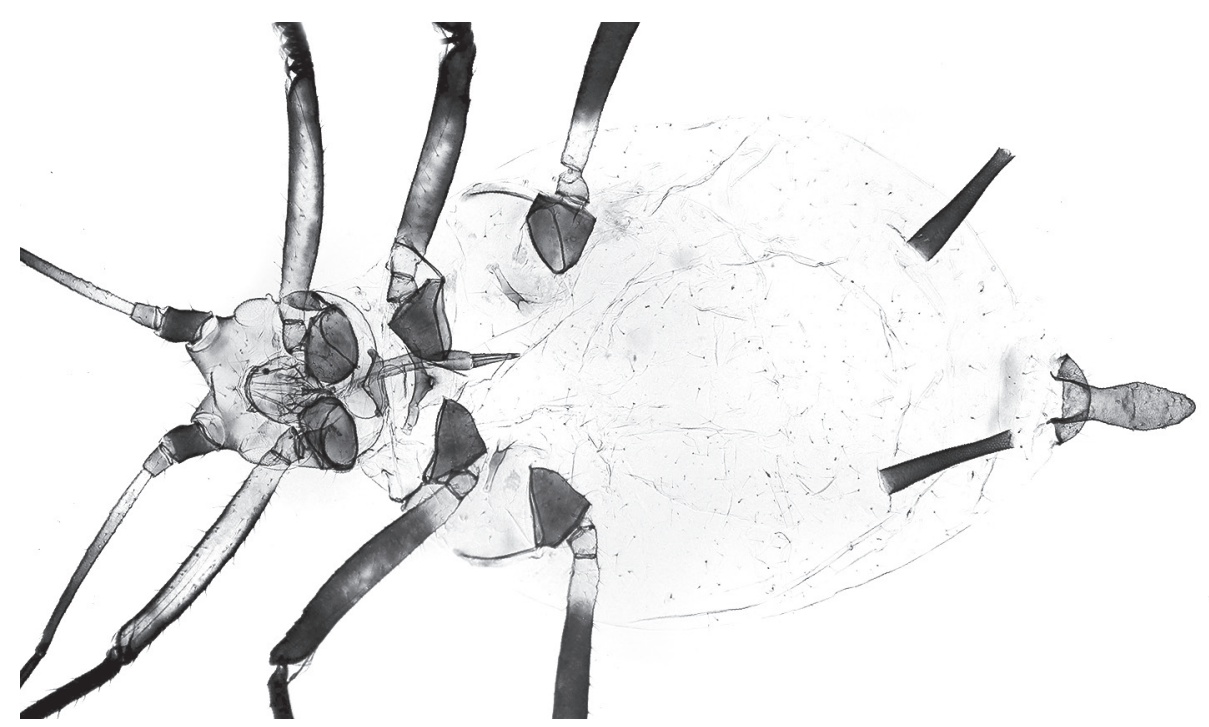

Fig. 4. Macrosiphoniella artemisiae 
Centaurea arenaria was colonized by Uroleucon jaceae L. in 5 locations.

Uroleucon jaceae is monoecious, holocyclic on Centaurea species. Colonies are formed on the upper parts of stems of Centaurea spp. Uroleucon jaceae is widespread in Europe, Middle East, Central Asia and Pakistan. It occasionally occurs on other daisy species (Blackman and Eastop, 2006).

Uroleucon jaceae is a large blackish aphid. (The body length is $3.0-4.5 \mathrm{~mm}$ long.) The abdominal tergites 2-4 often have small marginal tubercles about the size of hair bases. The basal half of femona is pale, the distal part is dark, with a rather sharp transition between them. The tibiae are totally black. The distal half of siphunculi is reticulated. The cauda is dark and bears 18-30 hairs (Fig. 6).

Uroleucon jaceae colonized Centaurea stoebe subsp. micranthos on two locations.

Carduus acanthoides L. was colonized by Uroleucon aeneum (Hille Ris Lambers) on 3 locations.

Uroleucon aeneum forms colonies on the upper parts of stems of thistles (Cirsium, Carduus, Onopordum and Silybum species). U. aeneum is monoecious and holocyclic on thistles. The area of distribution of the species is Europe, Turkey, Armenia, Kazakhstan and Eastern Siberia (Blackman and Eastop, 2006).

Uroleucon aeneum is shiny metallic bronze-black large aphid (body length is 3.0$4.3 \mathrm{~mm}$ ). Cauda is black. The tibiae have paler middle section. The distal half of the hind femur is dark. Abdominal hairs originating from dark scleroits. The distal 1/5 of the black cornicles has polygonal reticulation (Fig. 7).

Artemisia absinthium accommodated Macrosiphoniella absinthii (L.) in two locations.

Macrosiphoniella absinthii occurs in northern and Central Europe eastward to Siberia and Iran. Macrosiphoniella absinthii is also found in North Africa and the Mediterranean area, and has been introduced to the USA, Canada and Argentina (Blackman and Eastop, 2006).

In life Macrosiphoniella absinthii is reddish-brown wax-powdered aphid. It has a black head, antennae, legs, siphunculi and cauda, and a black spot in the centre of the abdomen which is highlighted by a white surround of powdered wax. The hind tibiae are black from the base to apex. The spinal body hairs are originating from dark scleroites. The siphunculi are very thick and short and are reticulated on the apical $48-60 \%$. The body length of Macrosiphoniella absinthii apterae is 1.7-2.5 mm (Fig. 8).

Achillea millefolium L. was colonized by Macrosiphoniella millefolii (De Geer, 1773) in two locations.

Macrosiphoniella millefolii forms colonies especially in the inflorescence of Achillea millefolium. Macrosiphoniella millefolii is common in Europe; it is present in West Siberia. The species was introduced to North America (Blackman and Eastop, 2006).

Apterae of Macrosiphoniella millefolii are of moderate size, green and wax powdered except for a spinal stripe on the abdomen and antesiphuncular spots. The antennae, siphunculi and cauda are black; the legs are mostly black except for the basal part of the front femur which is brown. Dark sclerites are present on the sides and just in front of the siphunculi. The long body hairs on the dorsum originating from dark scleroites; some of these may be fused into larger sclerites (Fig. 9). 


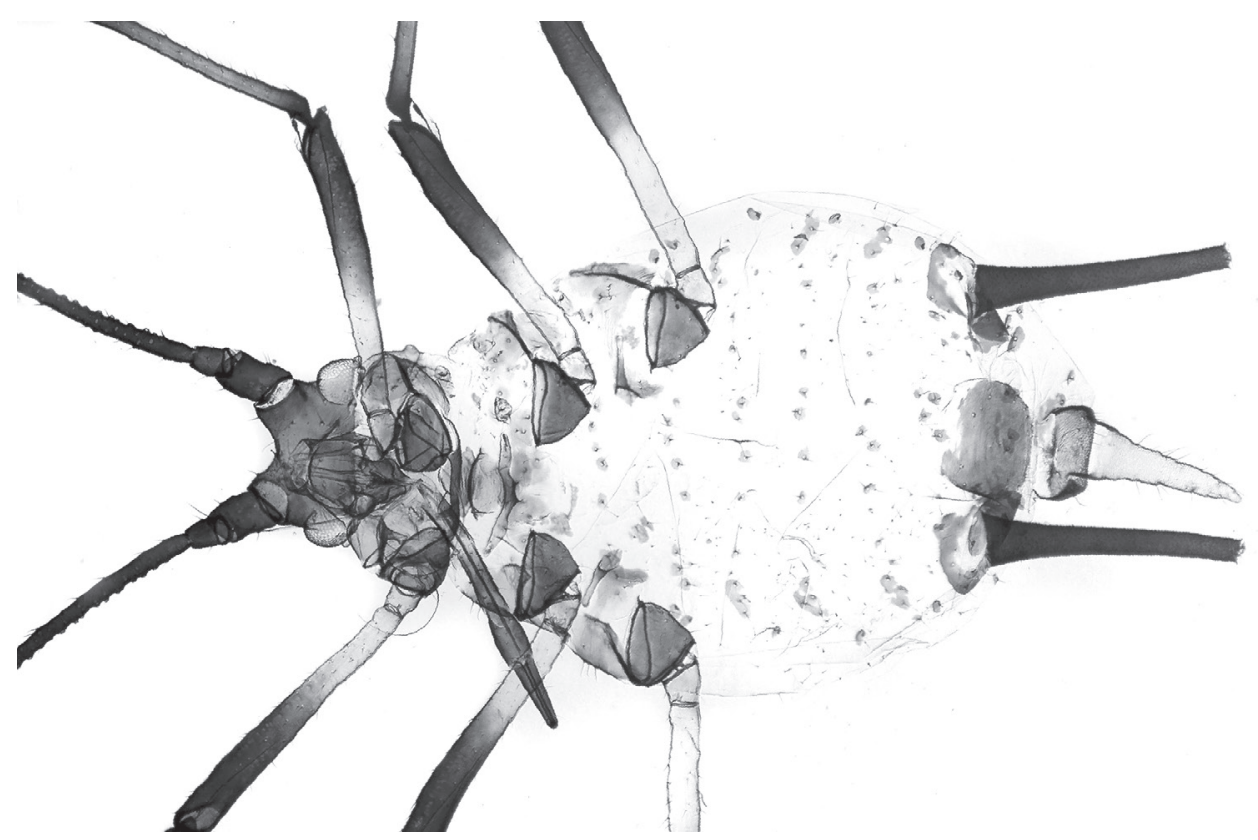

Fig. 5. Uroleucon cirsii

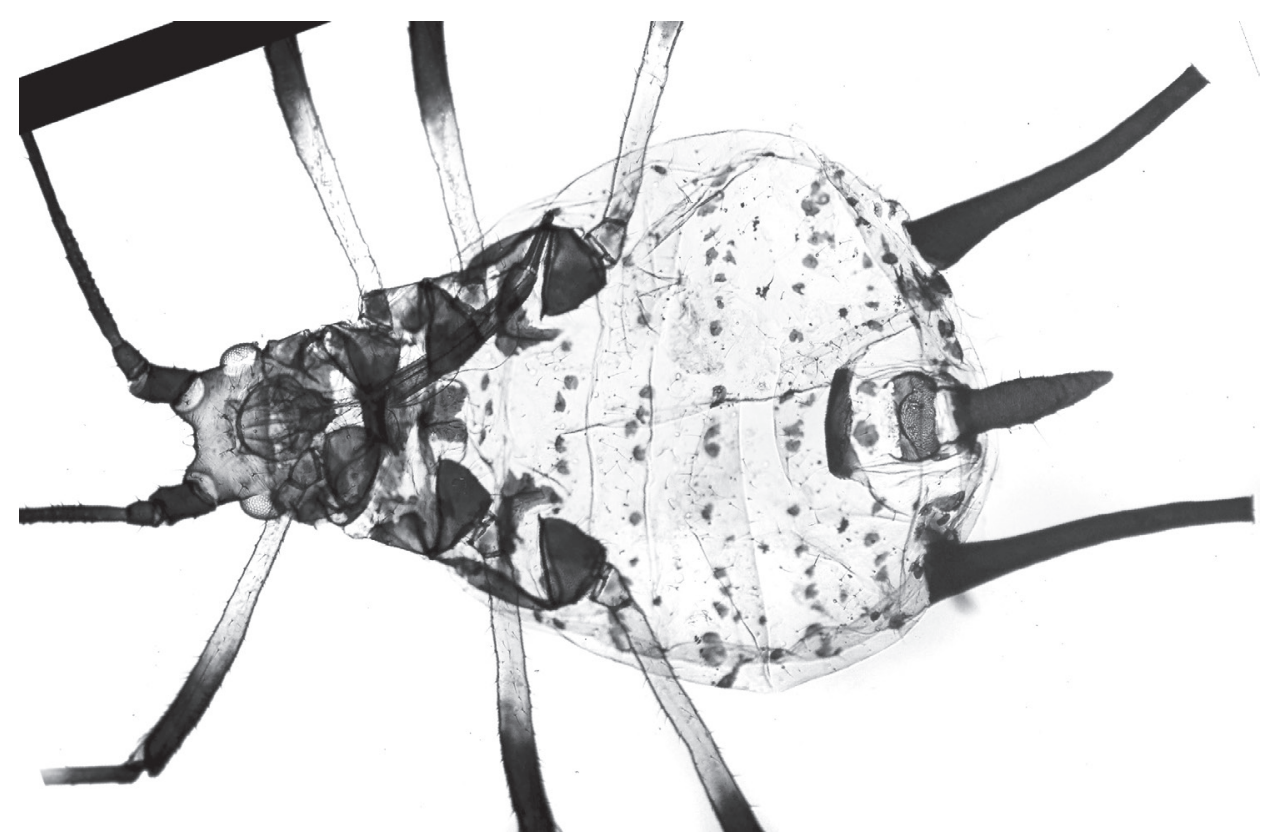

Fig. 6. Uroleucon jaceae 


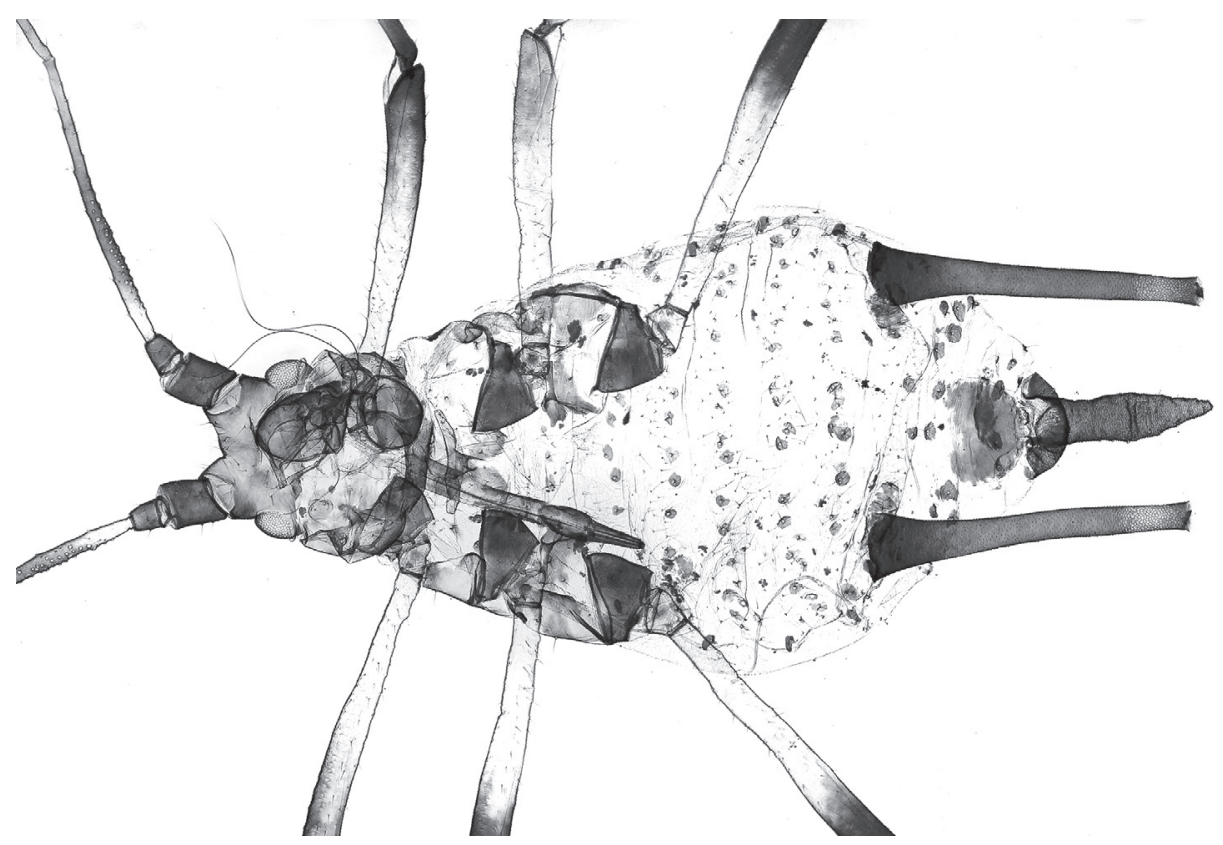

Fig. 7. Uroleucon aeneum

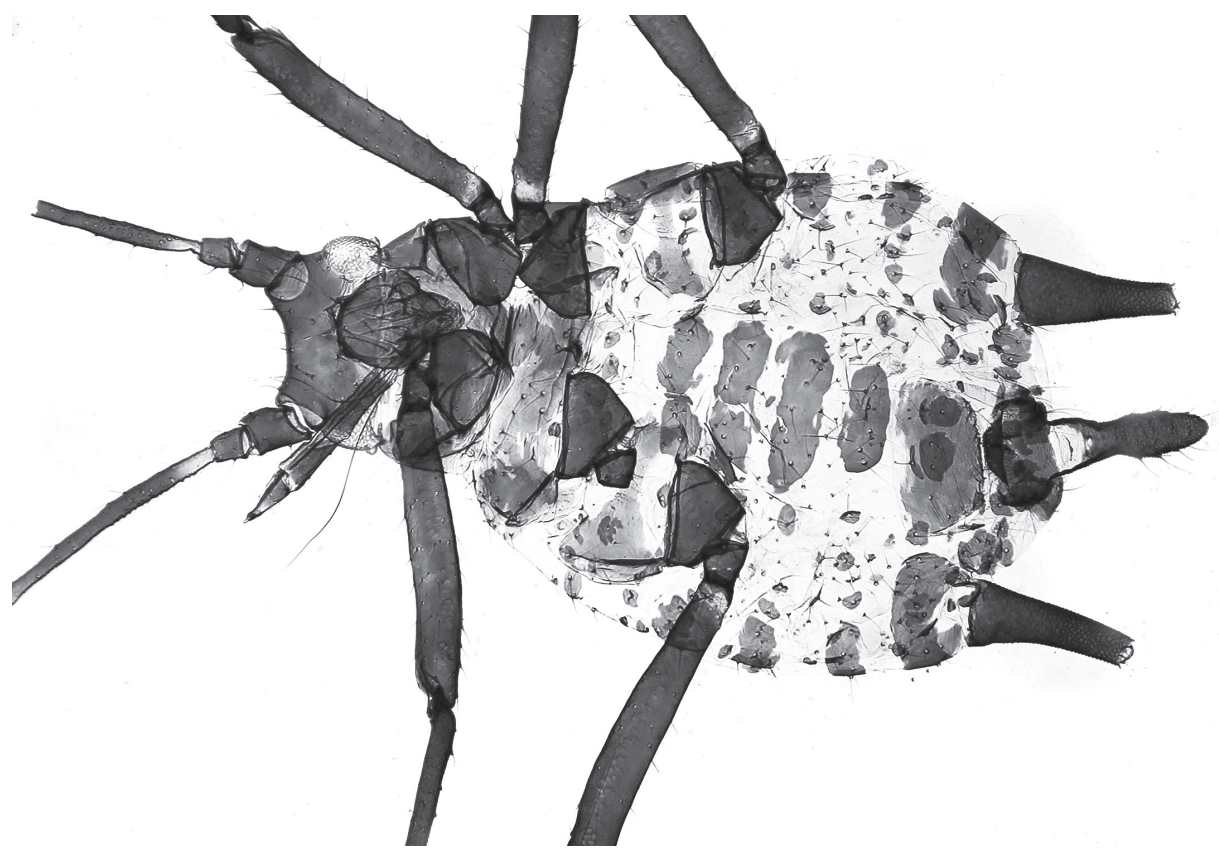

Fig. 8. Macrosiphoniella absinthii 


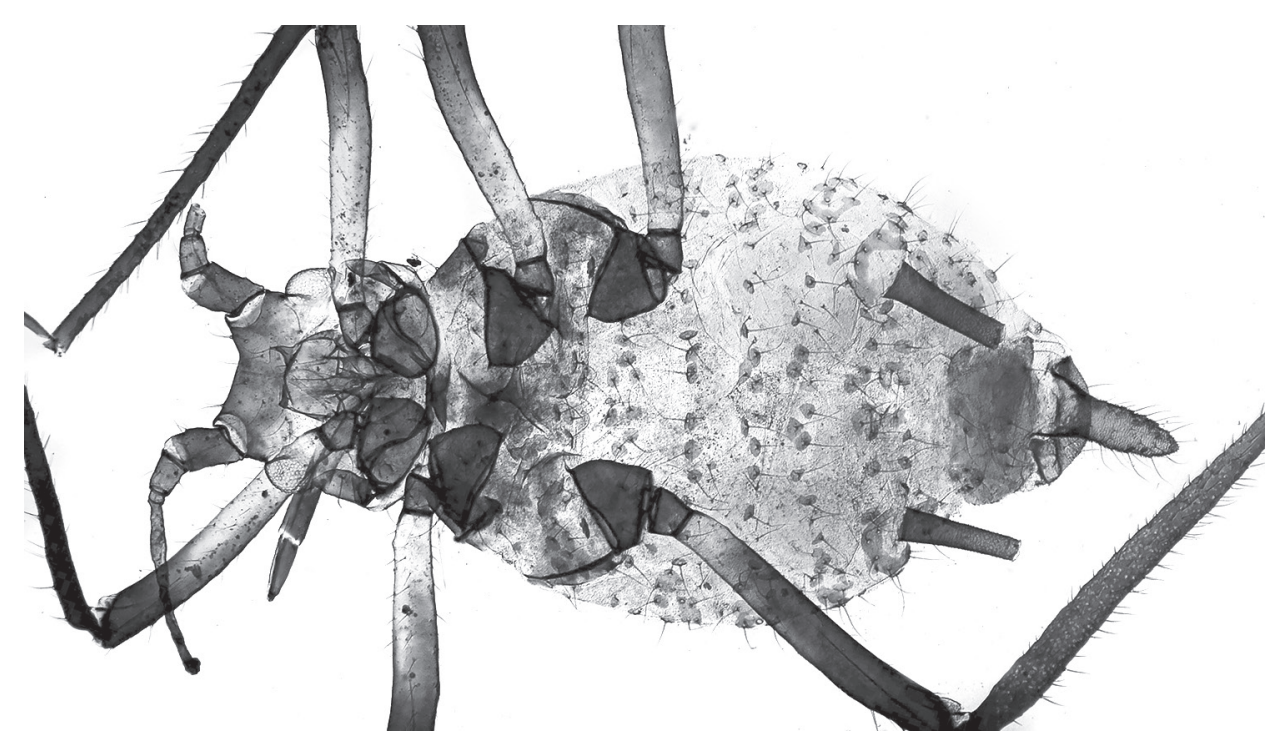

Fig. 9. Macrosiphoniella millefolii

\section{Discussion}

Uroleucon cichorii, Aphis intybi and Aphis fabae cirsiiacanthoidis colonies occurred on Cichorium intybus. Cirsium arvense was colonized by Aphis fabae cirsiiacanthoidis. Artemisia vulgaris accommodated Macrosiphoniella artemisiae. The annual Crepis setosa was the host plant of Uroleucon cichorii. The perennial Picris hieracioides also accommodated Uroleucon cirsii. Centaurea arenaria and Centaurea stoebe subsp. micranthos accommodated Uroleucon jaceae. Carduus acanthoides was colonized by Uroleucon aeneum. Artemisia absinthium was the host of Macrosiphoniella absinthii. Achillea millefolium was colonized by Macrosiphoniella millefolii.

\section{Acknowledgements}

The author wishes to thank for financial support of OTKA project number 83829. Grateful thanks are due to Dr. Géza Ripka for his valuable advices during manuscript preparation, Ágnes Valiskó Hornyák for mounting the slides and Dr. Éva Szita for the microscopic photography. Special thanks are due to Dr. Zsolt Kárpáti and Dr. Béla Molnár for providing the facilities for microscopic photography supported by HAS Infrastructure Development project IF-014/2013.

\section{Literature}

Basky, Z. (2015): Brachycaudus species on herbaceous plants along highways in Hungary. Acta Phytopathol. et Entomol. Hung. 50, 67-75. DOI: 10.1556/038.50.2015.1.6 
Blackman, R. L. and Eastop, V. F. (2006): Aphids on the World's Herbaceous Plants and Shrubs. The Natural History Museum. John Wiley and Sons Ltd. England, Vol. 1. Host lists and keys. 1024 p., Vol. 2. The Aphids. 1415 p.

Forman, R. T. T., Sperling, D., Bissonette, J. A., Clevenger, A. P., Cutshall, C. D., Dale, V. H., Fahrig, L., France, R., Goldman, Ch. R., Heanue, K., Jones. J. A., Swanson, F. J., Turrentine, Th. and Winter, Th. C. (2002): Road Ecology. Science and Solutions. Island Press, Washington, Covelo, London, 481 p.

Király, G. (ed.) (2009): Új magyar füvészkönyv. Magyarország hajtásos növényei. Határozókulcsok. [New Hungarian Herbal. The Vascular Plants of Hungary. Identification Key.]. Aggteleki Nemzeti Park Igazgatóság, Jósvafö, 616 p. (in Hungarian)

Kiss, B., Lengyel, G., Nagy, Z. and Kárpáti, Z. (2013): First record of spotted wing Drosophila [Drosophila suzukii (Matsumura, 1931)] in Hungary. Növényvédelem, 49, 97-99. (in Hungarian)

Szalay-Marzsó, L. (1969): Levéltetvek a kertészetben. (Aphids in Horticulture.) Mezőgazdasági Kiadó, Budapest, 186 p. (in Hungarian)

Stoetzel, M. B. and Russell, L. M. (1991): Aphis intybi, a pest of chichory intercepted at United States ports of entry. Ent. Gener. 16, 147-155. 